\title{
Examining date rape interventions to improve health and wellbeing in college students
}

\author{
Victor G Aeby*, Tracy Carpenter-Aeby, Hanna-Lee Adkins, Jesse Hazel and Liz Waters \\ Department of Health Education and Promotion, East Carolina University, USA
}

\begin{abstract}
College is a time for exploration and learning for most students. However, college also presents unique risks and dangers. Date rape is a pervasive problem across college campuses nationwide. The contextual nature of date rape makes it difficult to define, and the dearth of critically evaluated interventions may lead to the perpetuation of ineffectual programs. The authors conducted a systematic literature review to elucidate the definitions of date rape in health and social work literature, identify effective interventions, and explore the nature of victims and perpetrators. Using the key words, date rape, interventions, and health, articles $(\mathrm{N}=69)$ from 1984-2015 were retrieved from seven online academic search engines. Peer reviewed articles from the last 10 years resulted in articles $(n=12)$ that included qualitative research studies, quantitative research studies, and outcome studies of interventions, and victim-perpetrator characteristics. Several studies illustrated successful interventions, while others indicated the need for the improvement of the current model of date rape interventions adopted by many college campuses. By critically evaluating intervention programs and, perhaps, abandoning intervention models that encourage victim-blaming, college campuses could adopt effective practices to prevent the occurrences of date rape, improve student health and well-being, and assure parents that campus safety is a priority.
\end{abstract}

\section{Background}

Date rape (sometimes called acquaintance rape) is an issue that many college administrators struggle with as they try to keep their campuses safe for students. Due to the contextual and delicate nature of acquaintance rape, many colleges have instituted interventions for which little evidence exists to suggest the effectiveness of these programs. Many interventions are still based on "the miscommunication hypothesis," which suggests that acquaintance rape occurs in part due to miscommunication between men and women about sexual consent [1]. Although little evidence points to the effectiveness of this approach, many colleges and universities implement this into their intervention programs, often with the stance of "risk management" [2]. While risk management may prove to be a helpful factor in helping women identifies potentially dangerous situations, the implications are still that it is the responsibility of women to avoid being raped. This approach may perpetuate the cycle of victim blaming, and ignores the reality that the vast majority of rapes are not perpetrated by strangers but are committed by men that are trusted by their victims [3].

Instead of continuing the oversimplified risk-management approach, it has been suggested by many researchers that colleges and universities adapt to the statistical realities of date rape and modify their interventions [4]. Many other campus interventions focus on the role of women's assertiveness in mitigating sexual aggression. While women should be encouraged to protect themselves to their best ability, this again largely places the responsibility to prevent sexual aggression on the women, again encouraging attitudes of victim blame. It is evident, because many campus date rape interventions are largely ineffective, that new models of date rape interventions need to be identified and tested. If colleges and universities are invested in providing safe campuses, they need to acknowledge that date rape and sexual aggression are too complicated to be mitigated by sexist and oversimplified educational techniques.
After systematic review of current literature pertaining to date rape interventions, it becomes clear that for date rape interventions to be effective for college campuses, a variety of factors should be addressed. Many researchers recommend involving men in the intervention, because the large majority of date rape perpetrators are male [2]. Others emphasize that the common date rape prevention strategies such as "emergency phones, lighting, campus escort services, and other target-hardening approaches" perpetuate the stranger-rape myths while minimizing the prevalence of rape by trusted peers [5]. While it is important to have such features on campuses for safety measures, perhaps colleges and universities should develop a diversified, holistic approach to acquaintance rape intervention. An intervention that combines practical safety and risk management features with assertiveness training, while including male students in education and training, may be the approach that is needed to help mitigate the prevalence of sexual aggression. The theoretical implications of developing an integrated approach to date rape interventions are the possibility of colleges and universities adopting intervention programs that are effective in keeping their students safe while teaching valuable life skills to students of both genders.

Fisher and a few of her colleagues did a literature review focused on the role that research could play in the development of prevention programs and risk reduction interventions. The first suggestion is that prevention education should begin at an early age and extend throughout life, considering that a great number of women experience rape earlier in life. Also, being that women between the ages of 16 and

${ }^{*}$ Correspondence to: Victor G Aeby, Department of Health Education and Promotion, East Carolina University, USA, E-mail: AEBYV@ecu.edu

Key words: date rape, acquaintance-rape, intervention, prevention, college students

Received: September 26, 2018; Accepted: October 04, 2018; Published: October 08,2018 
24 are the most vulnerable to rape, they should specifically be targeted. Men should also be targets of prevention programs because males are the most likely offenders. Another population that Fisher suggested should be targeted by prevention programs are victims of rape, to prevent revictimization. Fisher e also suggested seven key concepts that should be included in prevention programs. These seven concepts are Awareness and Knowledge About Rape, Rape Myths and Rape Supportive Attitudes, Alcohol Consumption, Effective Self-Protection Strategies, Self-Defense Training, Telling a Friend, and Health CareBased Interventions.

In another study done by Laura G. Hensley addressed issues with treating rape victims and useful interventions for treating victims who experience PTSD symptoms. There are four issues that are important when treating rape survivors, which are history of victimization, nature of the assault, victim-blame exposure, and sociocultural influences on the victim's response to rape. Addressing these four issues will help counselors better understand the victims experience and allow them to provide better treatment. Hensley suggested a multimodal treatment approach for rape survivors. This intervention consists of four treatment strategies used to target specific PTSD symptoms: the provision of education about common PTSD symptoms via psych education, the facilitation of the client's repetition of the details of the event through exposure based techniques, challenging the client's beliefs about her role in the cause of the rape via cognitive restructuring, and the enhancement of coping skills by using anxiety-management techniques.

Surprisingly, there were a number of connections between the older and current articles. Regardless of article age, most of the articles focused on changing rape related attitudes, rape myths, and victim blaming as a way to decrease the prevalence of rape. The articles also focused more on the woman being the agent for change by learning self-defense techniques and ways to reduce risk factors $[2,3,6]$. The problem is that, although there are many rape prevention programs that are successful at changing various factors that play a role in the prevalence of date rape, date rape is still a very large problem on college campuses across the country $[7,8]$. There are very few successful interventions targeting college students $[1,7,8]$.

After realizing that the term "date rape" can be interpreted in many different ways, it was necessary to research alternative interventions on how to define and deal with date rape. Scholarly databases uncovered 30 articles by researching different variations of the word date rape such as "acquaintance rape" and also using the keywords "interventions" and "college students." In addition, there were articles (N=29) from 20042014 using the key terms sexual assault and campus. The Independent variable would be the evidenced-based interventions with date rape (sexual assault) victims on campus and the dependent variable would be the studies resulting from the systematic literature review. It is believed that the current methods of date rape interventions on college campuses are not effective and may benefit from a more integrated approach. After examining articles pertaining to interventions with victims of date-acquaintance rape on college campuses, it is apparent to affect change from victim blaming-shaming to awareness, it may be beneficial to implement updated interventions that can better serve the college community.

Date rape and sexual aggression are enormous threats to students on college campuses across the country. While these problems are garnering increasing political, media and social attention, college campuses still lag behind producing and implementing current research. By examining existing literature across disciplines, the authors hope to identify effective preventions and interventions that would be reasonable for college campuses to integrate into their curricula. Articles were reviewed systematically following the "Cochrane Review" format (Table 1).

\section{Literature review}

\section{Misconceptions about date rape}

A study by Bouffard \& Bouffard [5], examined how men perceive date rape in an attempt to begin to identify certain attitudes that could predispose men to engaging in sexual violence. The study indicated that date rape was correlated with rape-supportive attitudes as well as the idea that the perceived "benefits" outweighed the consequences [5]. The idea that sexual aggressors perform a type of "cost-benefit" analysis illustrates the concept that date rape and sexual assault are too complicated to solve by risk management and assertiveness strategies targeted towards women alone. Many college campuses focus on date rape and sexual assault prevention in a context that is not realistic. A study conducted by Cass [7], highlights the evidence that most occurrences of sexual violence on college campuses occur by "partners and friends in accustomed, residential spaces," not by "strangers lurking in unlit parking lots" [7].

Many date rape and sexual assault preventions follow the "miscommunication hypothesis," which is the idea that date rape results from miscommunication regarding sexual consent between intimate partners [1]. In essence, "miscommunication theory suggests that miscommunication can manifest in three different ways: (a) men over perceiving women's sexual interest, (b) men misreading women's refusals as modesty, and (c) women saying no when they mean yes (the "token no")" [1]. While very little evidence exists to support such extensive misunderstanding between men and women, many college campuses adopt this theory nonetheless. New evidence was found to the contrary of the miscommunication hypothesis, which indicates

Table 1. Methodology for Systematic Literature Review Based on the Cochrane Model

\begin{tabular}{|c|c|}
\hline $\begin{array}{l}\text { 1. Defining the review question and } \\
\text { developing criteria for including studies }\end{array}$ & $\begin{array}{l}\text { How many articles are in the professional } \\
\text { literature (scholarly peer reviewed) using } \\
\text { specific search engines and the key words, } \\
\text { date rape, interventions, and health from } \\
2005-15 ?\end{array}$ \\
\hline 2. Searching for studies & $\begin{array}{l}\text { 1. Search engines: Social Work } \\
\text { Abstracts, Education Research Complete, } \\
\text { PsychArticles, PsychINFO, SocIndex with } \\
\text { Full text, Alt HealthWatch, Women's Studies } \\
\text { 2. Scholarly Peer Reviewed } \\
\text { 3. } 2005-2015 \\
\text { 4. Key words: date rape, interventions, } \\
\text { and health }\end{array}$ \\
\hline 3. Selecting studies and collecting data & $\begin{array}{l}\text { Key words: date rape, interventions, and } \\
\text { health in the title }\end{array}$ \\
\hline 4. Assessing risk of bias in included studies & $\begin{array}{l}\text { Choice of key words. Different key words } \\
\text { might yield additional articles; May not } \\
\text { include all literature; } \\
\text { Choice of Search engines. Not all inclusive }\end{array}$ \\
\hline 5. Analyzing data & $\begin{array}{l}\text { Create Tables } 2 \text { and } 3 \text { to determine how } \\
\text { many articles and then examine themes in } \\
\text { articles }\end{array}$ \\
\hline 6. Addressing and reporting biases & Face validity table \\
\hline $\begin{array}{l}\text { 7. Presenting results and "summary of } \\
\text { findings" tables }\end{array}$ & $\begin{array}{l}\text { Table } 2=\# \text { of articles within in this search } \\
\text { Table } 3=\text { themes of articles, who wrote } \\
\text { them, what disciplines, what do they tell us }\end{array}$ \\
\hline $\begin{array}{l}\text { 8. Interpreting results and drawing } \\
\text { conclusions }\end{array}$ & $\begin{array}{l}\text { Base on the existing literature defining } \\
\text { the problem (in the Introduction) and } \\
\text { comparing the articles in the SLR - what } \\
\text { exists and where to apply the information }\end{array}$ \\
\hline
\end{tabular}


that most men are quite adept at reading verbal and nonverbal cues [1]. A study conducted by Schewe and O'Donohue supported the miscommunication hypothesis as well by claiming that failure to perceive negative cues from women could lead a perpetrator to overestimate the benefit and underestimate the cost of unwanted sexual advances. According to Edwards and Headrick, many paint the image of a rapist as a shady, smelly, and racialized individual that lurks in the bushes waiting for a victim (Edwards \& Headrick, 2008). This is not always true because most women who are raped know the perpetrator.

The overwhelming majority of interventions for college students focus on the idea that women are responsible for preventing their own sexual assault. A study by Smith, White, and Holland [9], examined dating violence among adolescent college-age women in an attempt to examine the attitudes of women who experienced childhood victimization and then were in a vulnerable state for being a victim of date rape. "There is a need for dating violence prevention/ intervention programs in high school and college and for research on factors that reduce revictimization [9]." Earle [10] did a study that used acquaintance rape workshops to change the attitudes of first year college-men. In this study, there was exclusive emphasis on what women can do to prevent rape. However it supports the attitude that women are responsible for rape and it was said that if interventions are designed only for women, they might give women a false sense of security. "There is nothing a woman can do to guarantee that she will not be victimized. It is important to address the question of how women can protect themselves, but it is also of vital importance to develop interventions in which men are the target [10]".

\section{Common prevention strategies for college students}

Many college campuses offer some type of education or training for first year students. A study by Rothman, et al. [8] examined the effects of a campus prevention program on first year students' sexual violence victimization rates. Many college interventions for date rape target heterosexual female audiences and do not focus heavily on these issues affecting other groups such as heterosexual men or homosexual students of either sex [8]. Their results indicate that such programs are only marginally effective at reducing rates of victimization. Another existing date rape prevention tool is the DATE program. The DATE program uses a risk management perspective to educate and train women to respond assertively to sexual coercion. [11]. An evaluation of the DATE program indicated that it was effective in reducing victimization rates in that women who had received the training were more likely to respond assertively and less likely to be victimized by sexual coercion [11]. Alcohol and drug use education are other common tools many college campuses use as a prevention strategy to promote safety among students. Alcohol and drug use are strongly correlated with incidences of date rape and sexual violence [3]. Along the same lines, Jordan [12] conducted research that examined sexual assault/ date rape interventions in college freshman. It was found that rape is committed more often than any other violent crime on college campuses and many intervention studies lack evaluation data to demonstrate effectiveness of education about date rape on college campuses.

Lanier, et al. [13] led a study that merely focused on evaluating date rape interventions as a whole. They used the College Date Rape Attitude Survey (CDRAS), a measure intended to assess attitudes related to risk for committing rape in adolescents and young adults. The survey was administered to determine the principal component structure of raperelated attitudes in data collected on an undergraduate college sample.
"Because of this reported prevalence of sexual victimization on college campuses, educators have called for rape prevention programming. As a result, there have been a number of programs that have focused on changing attitudes related to rape or to measure adherence to rape myths [13]". Exner and Cummings [14] did research on college students as bystanders to sexual assault prevention. There is a need for gender-targeted prevention programming that introduces the idea of prosocial bystander intervention, with a focus on increasing selfefficacy and lowering barriers. Schewe and O'Donohue talked about the work of Bandura in their study. They highlighted that Bandura's theory suggested, "interventions that alter rape supportive cognitions, decrease problematic rape outcome expectancies, or increase victim empathy could work to decrease the amount of sexual aggression committed by men".

Increasing bystander efficacy and willingness to intervene on rape awareness on college women was a study conducted by Foubert, et al. [15]. This study aimed to measure whether a rape awareness program designed for college women, The Women's Program [15], can produce results, whereby women report greater efficacy and willingness to prevent rape from happening to other women when they themselves are in the bystander position. Ely (2005) did a study on preventing adolescent dating violence on school campuses. "Research has shown that up to $43 \%$ of students report dating violence occurring on school grounds. School social workers and other school personnel must develop intervention programs based on empirical evidence to prevent adolescent dating violence on school campuses [16]". Some prevention programs focus on teaching women how to control environmental factors, which contribute to the likelihood of them, being targeted by a predator. They teach things such as what not to wear, not to consume too much alcohol, don't walk alone at night etc. The programs are aimed primarily at women. These types of programs reinforce the misconceptions that the ultimate responsibility for preventing rape lies with women instead of with the men who perpetrate such acts.

\section{New ideas for campus safety and date rape prevention}

Some studies indicate that assertiveness training techniques may be effective for enhancing the safety of female college students. While "risk management" techniques may be overly simplistic, assertiveness training could yield promising results for the female student population. Macy, et al. [17] found that many women in a date rape scenario are in the precarious situation of trying to maintain their physical safety and wondering if they should engage in behaviors to preserve the relationship with a person they thought they could trust. As such, prevention programs that help women "anticipate and respond" to sexual coercion and potentially dangerous situations may help reduce victimization rates among college women [17]. Along the same lines of assertiveness training, use of the Protection Motivation Theory in prevention and training programs may be promising for female students to learn to assess dangerous situations [2].

The University of Missouri-Columbia found a novel way to create a safer campus community while utilizing resources already existing within the campus. The university partnered with their School of Social Work to create a clinic to serve the needs of victims of date rape and sexual violence [7]. The clinic eventually grew to offer field internships to Social Work students. Such a team approach among various segments of college campuses may offer benefits to students, universities, and most importantly, the victims themselves. Other evidence for successful preventions comes from an evaluation of the effectiveness of three school-based sexual violence prevention 
programs [18]. While the particular interventions used in this study were targeted towards school-aged populations in middle school and high school, the results indicate the need for messages to be tailored to the audiences [18]. This concept can no doubt be integrated into use for college-aged populations as well.

In a study done by Senn [6] that was based on the education on resistance to acquaintance sexual assault, the program was successful in increasing the belief that the young women were at personal risk of acquaintance rape and could defend themselves effectively if necessary while lowering negative attitudes related to rape which could harm women if they were later a victim of sexual assault [6]. In regards to males, Stewart [19] did research on sexual assault programs that target college men by using a project titled The Men's Project. The Men's Project integrates social norms, empathy, and bystander education programs into one program for college men. From baseline to posttest, participants reported reductions in sexism, rape myth acceptance, and gender-biased language use in addition to increases in collective action willingness, feminist activism, and bystander efficacy. Discussion centers on men's role in ending sexual violence and the need for more prevention programs targeting men.

According to a review done by Fisher, Daigle, and Cullen, women who are more at risk of rape than other women should be primarily targeted by rape prevention programs. They also suggested that prevention programs include education that is geared toward males because they are most likely the offenders. Seven key concepts that they believe should be included in prevention programs are 1) awareness and knowledge of rape, 2) rape myths and supportive attitudes, 3) alcohol consumption, 4) effective self-protection strategies, 5) selfdefense training, 6) importance of telling a friend, and 7) health carebased interventions.

\section{Methods}

\section{Search methods}

Defining date rape: In order to identify effective intervention programs for preventing date rape and other forms of sexual violence on college campuses, it is necessary to define what meanings the term "date rape" encompasses. When used colloquially, date rape implies a romantic or "dating" relationship wherein an act of rape occurs. Acquaintance rape implies a relationship wherein the victim knows the assaulter, but is not involved in any kind of romantic relationship with them. Surprisingly, the literature uses the two terms interchangeably to describe cases of rape perpetrated by someone that is trusted by the victim, or otherwise seen as "companions" or "capable guardians" [4]. Sexual assault is certainly a difficult subject to discuss, and it often is easier to conceptualize acts of sexual violence as being perpetrated by a stranger instead of by a trusted friend or companion. However, although college campuses are eager to adopt a risk-reduction style of rape prevention, they appear to be hesitant to acknowledge that for students, danger exists not only in "strangers lurking in unlit parking lots," but also in familiar, trusted people in familiar spaces [4]. Modern sexual assault preventions and interventions should redefine their conceptualization of date rape in order to stop perpetuating misconceptions about the reality of sexual assaults on college campuses.

Selecting studies and data collection: The authors searched for articles pertaining to several variables: date rape, acquaintance rape, interventions, and college campuses and sexual assault. To qualify for selection, articles needed to include some type of intervention or prevention for date rape. Ideally, all articles would have been directly related to interventions specific to college campuses, but there is a decided lack of published articles that were both targeted towards college campus intervention while still meeting the criteria for date rape interventions. The authors utilized online academic search engines including Academic Search Complete, ERIC, PsycARTICLES, PsycINFO, Social Work Abstract, SocIndex with Full Text, Women's Studies International

The authors selected qualifying articles $(n=30)$ for review. Both qualitative and quantitative studies were selected in order to provide a detailed and comprehensive overview of date rape as a phenomenon, and recommendations for interventions to be adopted by college campuses. Articles ranged in publication from 1996-2014. While the original intent was to limit the search criteria to include articles no older than 10 years, it became abundantly clear that the issue of date rape on college campuses has been an issue endangering college students for much longer than that. The articles older than 10 years were selected based on their relevance to the problem, and help to illustrate that the academic community has been clamoring for an updated approach to date rape intervention for many years.

Assessing risk of bias: While researching interventions for date rape on college campuses, many biases arose. First, when entering the words "social work" into the search engine, it was not easy to find relevant articles pertaining to both social work and date rape interventions. However, many of the articles were from psychologybased journals. Secondly, personal biases came out by the choices of how to group the keywords when using the search engine.

Data analysis: Using the key words, date rape, interventions, and health, the researchers employed seven search engines, Social Work Abstracts, Education Research Complete, PsychArticles, PsychINFO, SocIndex with Full text, Alt. HealthWatch, Women's Studies, to determine the number of peer-reviewed articles that had been published in the last 10 years (2005-2015) as shown in Table 2. Literature review forms were completed on each study $(n=13)$. Three graduate research assistants (GRAs) conducted a content analysis of the forms and articles $(n=13)$. The GRAs then themed the articles separately and compared their results (Table 3 ).

Addressing and reporting bias: Risk of bias was managed by use of a matrix to include a wide variety of information about each study (Table 3). The authors examine factors such as authors, year of publication, type of study (whether qualitative or quantitative), number of participants per study, and data analysis techniques (Table 1). The definition of "date rape" was derived from the definitions found in existing literature. Journal articles were synthesized by content into three major themes discussed in the Results section.

\section{Results}

The authors reviewed the qualifying journal articles $(n=13)$ pertaining to date rape. Key words about the research question were used to find qualifying articles located in several academic databases (Table 2). Articles were synthesized by content and three themes emerged:

\section{Implications for school health}

Date rape is an oxymoron of the grandest proportion. It does not sound correct. It certainly does not describe the pain, sorrow, and humiliation of being raped. College students do not go on dates to be raped. Acquaintance rape has the same tone. It would be rape except the victim knew the perpetrator. These terms diminish the impact that rape has on the victim. 
Aeby VG (2018) Examining date rape interventions to improve health and wellbeing in college students

Table 2. Results for the Systematic Literature Review Using the Keywords Date Rape + Interventions + Health (N=69)

\begin{tabular}{|c|c|c|}
\hline \multicolumn{1}{|c|}{ Years } & Keywords & Limiters \\
\hline $1984-2014$ & Date rape + Interventions + Health & Number of Articles \\
\hline $1984-2014$ & Date rape + Interventions + Health & Peer reviewed \\
\hline $2005-2015$ & Date rape + Interventions + Health & 10 years \\
\hline $\begin{array}{l}\text { Search engines: Social Work Abstracts, Education Research Complete, } \text { PsychArticles, } \\
\text { PsychINFO, SocIndex with Full text, Alt. HealthWatch, Women's Studies }\end{array}$ & $\mathrm{n}=25$ \\
\hline
\end{tabular}

Table 3. Articles from the Systematic Literature Review Using Key Words Date Rape, Intervention, and Health 2005-2015 ( $\mathrm{n}=13$ )

\begin{tabular}{|c|c|c|c|c|c|c|}
\hline & Study & $\mathbf{N}$ & Design & Measures & Analysis & Outcomes \\
\hline 1 & Amar A, et al. [20] & $\begin{array}{l}157 \\
\mathrm{UG} \\
\mathrm{M} / \mathrm{F}\end{array}$ & Cross sectional & Survey & $\begin{array}{l}\text { ANOVA } \\
\text { Chi square }\end{array}$ & $\begin{array}{l}\text { Significant gender } \\
\text { indicated for date rape } \\
\text { attitudes, efficacy, and } \\
\text { intention to act as a } \\
\text { positive bystander }\end{array}$ \\
\hline 2 & Close S [21] & 1 & $\begin{array}{l}\text { Case study } \\
\text { Review of literature }\end{array}$ & $\begin{array}{l}\text { Relational BEhavior with } \\
\text { risk factors and sequelae }\end{array}$ & $\begin{array}{l}\text { Cross sectional } \\
\text { analysis }\end{array}$ & $\begin{array}{l}\text { "Dating and domestic } \\
\text { violence is a public } \\
\text { health concern" } \\
\text { future interventions } \\
\text { depend on definition } \\
\text { and scope of problem }\end{array}$ \\
\hline 3 & Coker A, et al. [22] & $\begin{array}{l}149 \\
\text { MX/ Am } \\
\text { Women } \\
18 \text { to } 35\end{array}$ & $\begin{array}{l}\text { Cross- } \\
\text { sectional secondary data } \\
\text { analysis }\end{array}$ & $\begin{array}{l}\text { Frequency of PV and co- } \\
\text { occurance of PV }\end{array}$ & Linear regression & $\begin{array}{l}\mathrm{PV} \text { is prevalent in many } \\
\text { forms. }\end{array}$ \\
\hline 4 & DeGue S, et al. [23] & $\begin{array}{l}140 \text { outcome evaluations of primary } \\
\text { prevention strategies }\end{array}$ & systematic review & $\begin{array}{l}\text { frequency of rigorous or } \\
\text { non-rigorous evaluation } \\
\text { designs }\end{array}$ & $\begin{array}{l}\text { pre-post and post only } \\
\text { designs }\end{array}$ & $\begin{array}{l}\text { Three rigorous } \\
\text { prevention significant } \\
\text { effects on sexually } \\
\text { violent behavior }\end{array}$ \\
\hline 5 & Herrman J [ 24] & & $\begin{array}{l}\text { Concept } \\
\text { Paper about Nurse's roles }\end{array}$ & Interview questions & & $\begin{array}{l}\text { Discusses definitions, } \\
\text { prevalence, application } \\
\text { to practice }\end{array}$ \\
\hline 6 & Howard D, et al. [25] & $\begin{array}{l}551 \text { undergraduate male/female } \\
\text { students }\end{array}$ & Web based survey & $\begin{array}{l}\text { Alcohol related sexual } \\
\text { assault }\end{array}$ & $\begin{array}{l}\text { Multivariate logistic } \\
\text { regression analysis }\end{array}$ & $\begin{array}{l}\text { Alcohol related sexual } \\
\text { assault is associated } \\
\text { with other risk factors } \\
\text { among females only }\end{array}$ \\
\hline 7 & Klem J, et al. [26] & adolescent females & $\begin{array}{l}\text { Theoretical paper (existential) } \\
\text { application to population }\end{array}$ & Review Literature & $\begin{array}{l}\text { meaning of death, } \\
\text { isolation and freedom }\end{array}$ & $\begin{array}{l}\text { Identification of } \\
\text { existential constructs } \\
\text { as framework for } \\
\text { treatment. }\end{array}$ \\
\hline 8 & Lanier C, et al. [13] & $\begin{array}{l}\mathrm{N}=755 \\
\mathrm{n}=442 \\
\mathrm{n}=312 \\
1 \text { not reporting } \\
\text { UG health \& kine-siology classes }\end{array}$ & survey & $\begin{array}{l}\text { The College Date Rape } \\
\text { Attitude Study (CDRAS) } \\
\text { 20-item likert scale on } \\
\text { attitudes toward date rape }\end{array}$ & $\begin{array}{l}\text { Reliability analysis } \\
\text { using Chronbach's } \\
\text { alpha }\end{array}$ & $\begin{array}{l}\text { Both genders socially } \\
\text { desirable } \\
\text { Entitlement, } \\
\text { Blame-shifting, } \\
\text { Traditional roles, } \\
\text { Overwhelming sexual } \\
\text { desire } \\
\text { Females less in } \\
\text { agreement with rape- } \\
\text { related activities }\end{array}$ \\
\hline 9 & Lowe L, et al. [27] & $\begin{array}{l}N=166 \text { male female students rural } \\
\text { Georgia } 14-21 \text { age }\end{array}$ & Health Class & $\begin{array}{l}\text { Survey:To examine } \\
\text { adolescent dating } \\
\text { violence on school } \\
\text { campuses. }\end{array}$ & $\begin{array}{l}\text { This study examines } \\
\text { a review of the } \\
\text { adolescent dating } \\
\text { violence literature } \\
\text { indicates that risk } \\
\text { factors occur in three } \\
\text { domains: individual, } \\
\text { familial and societal. }\end{array}$ & $\begin{array}{l}\text { Even though most } \\
\text { dating violence } \\
\text { studies take place in } \\
\text { school, school policies } \\
\text { generally do not address } \\
\text { dating violence. }\end{array}$ \\
\hline 10 & McCall-Hosenfeld J, et al. [28] & $\mathrm{N}=478$ & $\begin{array}{l}\text { Secondary data analysis } \\
\text { survivor characteristics versus } \\
\text { time }\end{array}$ & $\begin{array}{l}\text { Cross-sectional data } \\
\text { SANE affiliated hospitals } \\
\text { July } 2003 \text { to June } 2005 . \\
\text { Multivariable analysis }\end{array}$ & $\begin{array}{l}\text { consequence of } \\
\text { delayed treatment } \\
\text { sexual abuse. }\end{array}$ & $\begin{array}{l}\text { Median time for } \\
\text { presentation } 16 \mathrm{hrs} \\
\text { Assault by known } \\
\text { assailant associated w/ } \\
\text { delayed presentation }\end{array}$ \\
\hline 11 & Palm Reed K, et al. [29] & 554 Freshman $70 \%$ white female & $\begin{array}{l}\text { experimental bystander } \\
\text { prevention program } 90 \\
\text { minutes with traditionl } \\
\text { psychoeducational violence } \\
\text { prevention work shop. }\end{array}$ & $\begin{array}{l}\text { Approval of violence and } \\
\text { rape myth acceptance }\end{array}$ & $\begin{array}{l}\text { logistic regression } \\
(\mathrm{MLM})\end{array}$ & $\begin{array}{l}\text { Both programs } \\
\text { improved rape myth and } \\
\text { bystander scores }\end{array}$ \\
\hline 12 & Salazar L, et al. [30] & $\begin{array}{l}743 \\
\text { UG males age 18-24 }\end{array}$ & $\begin{array}{l}\text { Web based general health } \\
\text { program }\end{array}$ & $\begin{array}{l}\text { random sample, two } \\
\text { groups, self reports }\end{array}$ & $\begin{array}{l}\text { prosocial intervening } \\
\text { behaviors and sexual } \\
\text { violence perpetration }\end{array}$ & $\begin{array}{l}\text { participants intervened } \\
\text { more often and had } \\
\text { greater knowledge }\end{array}$ \\
\hline 13 & Talbot K, et al. [31] & 1602 college undergrad male female & $\begin{array}{l}\text { attitudinal survey; date rape and } \\
\text { attitudes toward women }\end{array}$ & cross sectional & $\begin{array}{l}\text { rape acceptance } \\
\text { attitudes }\end{array}$ & $\begin{array}{l}\text { males more accepting } \\
\text { than females, }\end{array}$ \\
\hline
\end{tabular}


The implications of the 1972 Title IX, an Educational Amendment of federal civil rights law, have always been for all students to have equal access to their education (US Congress, 1972). New complaints made the Department of Education as part of the national "End Rape on Campus" campaign linked sexual assault to a violation of Title IX (Clark, Pino, \& Karasek, n.d.). Survivors of sexual assault are not being afforded equal access to education. It is often the case that perpetrators of sexual assault do not face institutional consequences and criminal charges and are free to commit these crimes again. Survivors often have to alter their lives around avoiding their assailant on campus; thus, do not have access to an equal educational experience when educational institutions favor the "rights" of the perpetrator over the rights of the victim. Lack of institutional support can only re-victimize survivors of sexual assault. Universities have the ethical and legal obligation to ensure that known sexual predators are not prowling on their campuses.

Future preventions and interventions for sexual assault on college campuses should focus on challenging misperceptions and avoid victim blaming. It is the legal duty of institutions to ensure their students equal access to education. Universities and students would benefit from a multifaceted approach to prevention and intervention that includes equal measures of education, risk management, and interventions to increase empathy, assertiveness, and bystander effectiveness. Such efforts should include all students, regardless of gender or sexual orientation, and research suggests that individualized approaches are most effective in reaching target audiences. In developing future preventions and interventions that are realistic, universities must abandon the "miscommunication hypothesis." Since research has indicated that the miscommunication hypothesis is not actually grounded in reality, it only serves to perpetuate a cycle that excuses the perpetrator from any accountability while making it the responsibility of the victims to avoid being sexually assaulted. Educational institutions should strive to evolve past obsolete double standard and hold men equally accountable in preventing sexual assault.

Date rape and sexual assault are matters that a large numbers of colleges and universities battle with while working towards keeping their campuses safe for their student body. After doing extensive research, it is evident that numerous colleges have introduced interventions, but little evidence exists to propose the effectiveness of the intervention programs. There was much research that focused on working to change people's attitudes towards date rape, implementing interventions for date rape, working with men and their experiences with date rape, and more. Research on the subject of identifying effective interventions on college campuses overwhelmingly put great emphasis on the fact that colleges must find a way to implement better intervention systems for their college students pertaining to their safety and the possibility of being a victim of date rape. College students need to be made more aware of the realities of date rape and be supported by their educational institution when sexual assault occurs. The colleges themselves have to take sexual assault seriously and take accountability for the safety of their students on campus. Likewise, the duty of health educators, social workers, and other helping professionals is to support these colleges and to make sure they have the knowledge and resources necessary to ensure a safe college campus and college community.

\section{References}

1. Beres MA, Senn CY, McCaw J (2014) Navigating Ambivalence: How Heterosexual Young Adults Make Sense of Desire Differences. Journal of Sex Research 51: 765-776.

2. Singh S, Orwat J, Grossman S (2011) A protection motivation theory application to date rape education. Psychology, Health \& Medicine 16: 727-735.

3. Crawford E, Wright MO, Birchmeier Z (2008) Drug-Facilitated Sexual Assault: College Women's Risk Perception and Behavioral Choices. Journal of American College Health 57: 261-272.
4. Cass AI (2007) Routine Activities and Sexual Assault: An Analysis of Individual- and School-Level Factors. Violence \& Victims 22: 350-366.

5. Bouffard LA, Bouffard JA (2011) Understanding Men's Perceptions of Risks and Rewards in a Date Rape Scenario. Int J Offender Ther Comp Criminol 55: 626-645.

6. Senn CY (2013) Education on resistance to acquaintance sexual assault: Preliminary promise of a new program for young women in high school and university. Canadian Journal of Behavioural Science 45: 24-33.

7. Danis FS (2006) In Search of Safe Campus Communities: A Campus Response to Violence Against Women. Journal of Community Practice 14: 29-46.

8. Rothman E, Silverman J (2007) The Effect of a College Sexual Assault Prevention Program on First-year Students' Victimization Rates. Journal of American College Health 55: 283-290.

9. Smith PH, White JW, Holland LJ (2005) A Longitudinal Perspective on Dating Violence Among Adolescent and College-Age Women. Am J Public Health 93: 1104-1109.

10. Earle JP (2009) Acquaintance Rape Workshops: Their Effectiveness in Changing the Attitudes of First Year College Men. NASPA Journal 46: 417-433.

11. Simpson Rowe L, Jouriles EN, McDonald R, Platt CG, Gomez GS (2012) Enhancing Women's Resistance to Sexual Coercion: A Randomized Controlled Trial of the DATE Program. Journal of American College Health 60: 211-218.

12. Jordan JB (2011) Examining the effects of two sexual assault/date rape interventions in a population of college freshmen. Dissertation Abstracts International Section A 71: 2361 .

13. Lanier CA, Green BA (2006) Principal Component Analysis of the College Date Rape Attitude Survey (CDRAS): An Instrument for the Evaluation of Date Rape Prevention Programs. Journal of Aggression, Maltreatment \& Trauma 13: 79-93.

14. Exner D, Cummings N (2011) Implications for Sexual Assault Prevention: College Students as Prosocial Bystanders. Journal of American College Health 59: 655-657.

15. Foubert JD, Langhinrichsen-Rohling J, Brasfield H, Hill B (2010) Effects of a rape awareness program on college women: Increasing bystander efficacy and willingness to intervene. Journal of Community Psychology 38: 813-827.

16. Ely G (2005) Adolescent Dating Violence on School Campuses. Journal of EvidenceBased Social Work 1: 143.

17. Macy RJ, Nurius PS, Norris J (2006) Responding in Their Best Interests: Contextualizing Women's Coping With Acquaintance Sexual Aggression. Violence Against Women 12: 478-500.

18. Clinton-Sherrod AM, Morgan-Lopez AA, Gibbs D, Hawkins SR, Hart L, et al. (2009) Factors Contributing to the Effectiveness of Four School-Based Sexual Violence Interventions. Health Promotion Practice 19S-28S.

19. Stewart AL (2014) The Men's Project: A sexual assault prevention program targeting college men. Psychology of Men \& Masculinity 15: 481-485.

20. Amar A, Sutherland M, Laughon K (2014) Gender differences in attitude and beliefs associated with bystander behavior and sexual assault. Journal of Forensic Nursing 10: 84-91.

21. Close S (2005) Dating violence prevention in middle school and high school youth. Journal of Child \& Adolescent Psychiatric Nursing 18: 2-9.

22. Coker A, Sanderson M, Cantu E, Huerta D, Fadden M (2008) Frequency and types of partner violence among Mexican American college women. Journal of American College Health 56: 665-674.

23. DeGue S, Anne Valle L, Holt MK, Massetti GM, Matjasko JL, et al. (2014) A systematic review of primary prevention strategies for sexual violence perpetration. Aggression \& Violent Behavior 19: 346-362.

24. Herrman J (2009) There's a fine line....adolescent dating violence and prevention. Pediatric Nursing 35: 164-170.

25. Howard D, Griffin M, Boekeloo B (2008) Prevalence and psychosocial correlates of alcohol related sexual assault among university students. Adolescence 48: 733-750. [Crossref]

26. Klem J, Owens A, Ross A, Edwards L, Cobia D (2009) Dating violence: Counseling adolescent females from an Existential perspective. Journal of Humanistic Counseling Education \& Development 48: 48-64.

27. Lowe L, Jones C, Bank L (2007) Preventing dating violence in public schools: An evaluation of an interagency collaborative program for youth. Journal of School Violence 6: 69-87. 
Aeby VG (2018) Examining date rape interventions to improve health and wellbeing in college students

28. McCall-Hosenfeld J, Freund K, Liebschutz J (2009) Factors associated with sexual assault and time to presentation. Prev Med 48: 593-596. [Crossref]

29. Palm Reed K, Hines D, Armstrong J, Cameron A (2015) Experimental evaluation of a bystander prevention program for sexual assault and dating violence. Psychology of Violence 5: 95-102.
30. Salazar L, Vivolo-Kantor A, Hardin J, Berkowitz A (2014) A web-based sexual violence bystander intervention for male college students: Randomized controlled trial. $J$ Med Internet Res 16: 3-24.

31. Talbot K, Neill K, Rankin L (2010) Rape-accepting attitudes of university undergraduate students. Journal of Forensic Nursing 6:170-179.

Copyright: $(02018$ Aeby VG. This is an open-access article distributed under the terms of the Creative Commons Attribution License, which permits unrestricted use, distribution, and reproduction in any medium, provided the original author and source are credited. 